\title{
Globally Significant CO2 Emissions From Katla, a Subglacial Volcano in Iceland
}

DOI:

10.1029/2018GL079096

\section{Document Version}

Final published version

Link to publication record in Manchester Research Explorer

\section{Citation for published version (APA):}

Ilyinskaya, E., Mobbs, S., Burton, R., Burton, M., Pardini, F., Pfeffer, M. A., Purvis, R., Lee, J., Bauguitte, S., Brooks, B., Colfescu, I., Petersen, G. N., Wellpott, A., \& Bergsson, B. (2018). Globally Significant CO2 Emissions From Katla, a Subglacial Volcano in Iceland. Geophysical Research Letters, 45(19), 10,332-10,341. https://doi.org/10.1029/2018GL079096

Published in:

Geophysical Research Letters

\section{Citing this paper}

Please note that where the full-text provided on Manchester Research Explorer is the Author Accepted Manuscript or Proof version this may differ from the final Published version. If citing, it is advised that you check and use the publisher's definitive version.

\section{General rights}

Copyright and moral rights for the publications made accessible in the Research Explorer are retained by the authors and/or other copyright owners and it is a condition of accessing publications that users recognise and abide by the legal requirements associated with these rights.

\section{Takedown policy}

If you believe that this document breaches copyright please refer to the University of Manchester's Takedown Procedures [http://man.ac.uk/04Y6Bo] or contact uml.scholarlycommunications@manchester.ac.uk providing relevant details, so we can investigate your claim.

\section{OPEN ACCESS}




\section{Geophysical Research Letters}

\section{RESEARCH LETTER}

10.1029/2018GL079096

Key Points:

- Subglacial volcanoes are underrepresented in terms of gas monitoring, but we show that they can be major emitters of $\mathrm{CO}_{2}$

- Katla volcano is found to be one of largest volcanic sources of $\mathrm{CO}_{2}$ on the planet, contributing up to $4 \%$ of all nonerupting volcanoes

- High-precision airborne measurements combined with atmospheric modeling are a powerful method to monitor poorly accessible volcanoes

Supporting Information:

- Supporting Information S1

Correspondence to:

E. llyinskaya,

e.ilyinskaya@leeds.ac.uk

\section{Citation:}

Ilyinskaya, E., Mobbs, S., Burton, R., Burton, M., Pardini, F., Pfeffer, M. A., et al. (2018). Globally significant $\mathrm{CO}_{2}$ emissions from Katla, a subglacial volcano in Iceland. Geophysical Research Letters, 45, 10,332-10,341. https://doi. org/10.1029/2018GL079096

Received 5 JUN 2018 Accepted 10 SEP 2018 Accepted article online 17 SEP 2018 Published online 7 OCT 2018

\section{Globally Significant $\mathrm{CO}_{2}$ Emissions From Katla, a Subglacial Volcano in Iceland}

\author{
Evgenia llyinskaya' ${ }^{1}$ D, Stephen Mobbs ${ }^{2}$, Ralph Burton ${ }^{2}$, Mike Burton $^{3}$ (D, Federica Pardini ${ }^{3}$ (D), \\ Melissa Anne Pfeffer ${ }^{4}$ (D, Ruth Purvis ${ }^{5}$ iD, James Lee ${ }^{5}$, Stéphane Bauguitte ${ }^{6}$, Barbara Brooks ${ }^{2}$ (iD, \\ Ioana Colfescu $^{2}$, Gudrun Nina Petersen ${ }^{4}$ iD, Axel Wellpott ${ }^{6}$ iD, and Baldur Bergsson ${ }^{4}$ \\ ${ }^{1}$ School of Earth and Environment, University of Leeds, Leeds, UK, ${ }^{2}$ National Centre for Atmospheric Science, Fairbairn \\ House, University of Leeds, Leeds, UK, ${ }^{3}$ School of Earth and Environmental Sciences, Williamson Building, University of \\ Manchester, Manchester, UK, ${ }^{4}$ Icelandic Meteorological Office, Reykjavik, Iceland, ${ }^{5}$ National Centre for Atmospheric Science, \\ Innovation Way, University of York, York, UK, ${ }^{6}$ Facility for Airborne Atmospheric Measurements, Cranfield University, \\ Cranfield, UK
}

Abstract Volcanoes are a key natural source of $\mathrm{CO}_{2}$, but global estimates of volcanic $\mathrm{CO}_{2}$ flux are predominantly based on measurements from a fraction of world's actively degassing volcanoes. We combine high-precision airborne measurements from 2016 and 2017 with atmospheric dispersion modeling to quantify $\mathrm{CO}_{2}$ emissions from Katla, a major subglacial volcanic caldera in Iceland that last erupted 100 years ago but has been undergoing significant unrest in recent decades. Katla's sustained $\mathrm{CO}_{2}$ flux, $12-24 \mathrm{kt} / \mathrm{d}$, is up to an order of magnitude greater than previous estimates of total $\mathrm{CO}_{2}$ release from Iceland's natural sources. Katla is one of the largest volcanic sources of $\mathrm{CO}_{2}$ on the planet, contributing up to $4 \%$ of global emissions from nonerupting volcanoes. Further measurements on subglacial volcanoes worldwide are urgently required to establish if Katla is exceptional, or if there is a significant previously unrecognized contribution to global $\mathrm{CO}_{2}$ emissions from natural sources.

Plain Language Summary We discovered that Katla volcano in Iceland is a globally important source of atmospheric carbon dioxide $\left(\mathrm{CO}_{2}\right)$ in spite of being previously assumed to be a minor gas emitter. Volcanoes are a key natural source of atmospheric $\mathrm{CO}_{2}$, but estimates of the total global amount of $\mathrm{CO}_{2}$ that volcanoes emit are based on only a small number of active volcanoes. Very few volcanoes that are covered by glacial ice have been measured for gas emissions, probably because they tend to be difficult to access and often do not have obvious degassing vents. Through high-precision airborne measurements and atmospheric dispersion modeling, we show that Katla, a highly hazardous subglacial volcano that last erupted 100 years ago, is one of the largest volcanic sources of $\mathrm{CO}_{2}$ on Earth, releasing up to $4 \%$ of total global volcanic emissions. This is significant in a context of a growing awareness that natural $\mathrm{CO}_{2}$ sources have to be more accurately quantified in climate assessments, and we recommend urgent investigations of other subglacial volcanoes worldwide.

\section{Introduction}

Volcanoes are one of the most important natural sources of carbon dioxide $\left(\mathrm{CO}_{2}\right)$, but empirical measurements are available for only $20 \%$ of major volcanic gas emission sources (reviewed in Burton et al., 2013). Extrapolations of these measurements give an estimated a global subaerial geological emission rate of $\sim 1,500-\mathrm{kt} / \mathrm{d} \mathrm{CO}_{2}$ (Burton et al., 2013), which is $\sim 2 \%$ of the anthropogenic emission rate of $\sim 96,000 \mathrm{kt} / \mathrm{d}$ (Friedlingstein et al., 2010). Updated measurements of degassing from arc volcanoes, for example, Aiuppa et al. (2017), demonstrate that there are still large uncertainties. The quantification of $\mathrm{CO}_{2}$ emissions from previously unmeasured volcanic sources is therefore critical. While subglacial volcanoes are numerous, they are grossly underrepresented in terms of volcanic gas measurements ( 3 out of the 33 volcanoes reviewed in Burton et al., 2013), potentially because they often lack a visible gas plume and/or are more difficult to access. In Iceland, gas measurements of $\mathrm{CO}_{2}$ fluxes from the 32 active volcanic systems are sparse, and only 2 out of its 16 subglacial volcanoes (Grímsvötn and Eyjafjallajökull) have been measured (Table 1). The reported fluxes $\mathrm{CO}_{2}$ from nonerupting volcanoes are relatively low, with a maximum of $0.5 \mathrm{kt} / \mathrm{d}$ from Grímsvötn (Ágústsdóttir \& Brantley, 1994). Due to the low number of available measurements, the estimates of total volcanic $\mathrm{CO}_{2}$ flux in Iceland, 2.7-5.8 kt/d (Arnórsson \& Gislason, 1994; Hernández et al., 2012; 
Table 1

$\mathrm{CO}_{2}$ Flux (kt/d With Standard Error) From Katla Volcano Compared With Other Volcanoes in Iceland (kt/d, Minimum and Maximum Values) for Which Data Have Been Published

\begin{tabular}{|c|c|c|c|c|c|c|c|}
\hline \multirow[b]{3}{*}{ Volcano } & \multirow[b]{3}{*}{$\begin{array}{c}\text { Date (flight } \\
\text { number for Katla) }\end{array}$} & \multirow[b]{3}{*}{$\begin{array}{l}\mathrm{CO}_{2} \text { flux } \\
\text { (kt/d) }\end{array}$} & \multicolumn{5}{|c|}{ Methods } \\
\hline & & & \multirow[b]{2}{*}{ Approach } & \multicolumn{4}{|c|}{ Katla only } \\
\hline & & & & $\begin{array}{c}\text { Number } \\
\text { of flight } \\
\text { tracks }\end{array}$ & $\begin{array}{c}\mathrm{CO}_{2} \\
\max \\
(\mathrm{ppm})\end{array}$ & $\begin{array}{l}\text { Altitude of } \\
\mathrm{CO}_{2} \text { plume } \\
\text { ( } \mathrm{m} \text { above } \\
\text { sea level) }\end{array}$ & $\begin{array}{c}\text { Flux } \\
\text { calculation } \\
\text { method }\end{array}$ \\
\hline \multirow[t]{7}{*}{ Katla, western flank } & 18 Oct 2016 (B987) & $19.6 \pm 3.2$ & $\begin{array}{l}\text { Airborne direct } \\
\text { observations }\end{array}$ & 12 & 432 & $100-600$ & IDW \\
\hline & & 15 & Simulation & & & & SMF \\
\hline & 20 Oct 2016 (B989) & $14.6 \pm 3.2$ & Airborne direct & 13 & 413 & $840-1,200$ & IDW \\
\hline & & $11.9 \pm 5.4$ & observations & & & & Gaussian \\
\hline & & 5-10 & Simulation & & & & SMF \\
\hline & 04 Oct 2017 (C060) & $12.8 \pm 1.3$ & $\begin{array}{l}\text { Airborne direct } \\
\text { observations }\end{array}$ & 3 & 432 & $890-970$ & IDW \\
\hline & & $5-10$ & Simulation & & & & SMF \\
\hline \multirow[t]{2}{*}{ Katla, central caldera } & 04 Oct 2017 (C060) & $11.4 \pm 2.7$ & $\begin{array}{l}\text { Airborne direct } \\
\text { observations }\end{array}$ & 7 & 415 & $380-650$ & IDW \\
\hline & & $5-10$ & Simulation & & & & SMF \\
\hline $\begin{array}{l}\text { Grímsvötn (Ágústsdóttir \& } \\
\text { Brantley, 1994) }\end{array}$ & 1954-1991 & 0.53 & \multicolumn{5}{|l|}{$\begin{array}{l}\text { Subglacial melt water } \\
\text { from the caldera }\end{array}$} \\
\hline Eyjafjallajökull (Gíslason, 2000) & 2000 & $0.007-0.070$ & \multicolumn{5}{|l|}{$\begin{array}{l}\text { Subglacial melt water } \\
\text { from the caldera }\end{array}$} \\
\hline Hekla (Gislason et al., 1992) & 1988-1991 & 0.19 & \multicolumn{5}{|l|}{$\begin{array}{l}\text { Gas dissolved in } \\
\text { groundwater }\end{array}$} \\
\hline Hekla (Ilyinskaya et al., 2015) & 2012-2013 & 0.044 & \multicolumn{5}{|l|}{ Diffuse soil emissions } \\
\hline $\begin{array}{l}\text { Reykjanes (Fridriksson et al., 2006, } \\
\text { Fridriksson et al., 2010) }\end{array}$ & 2004-2009 & $0.012-0.019$ & \multicolumn{5}{|l|}{ Diffuse soil emissions } \\
\hline Hengill (Hernández et al., 2012) & 2006 & 0.45 & \multicolumn{5}{|l|}{ Diffuse soil emissions } \\
\hline Krafla (Ármannsson et al., 2007) & 2004-2006 & 0.23 & \multicolumn{5}{|l|}{ Diffuse soil emissions } \\
\hline
\end{tabular}

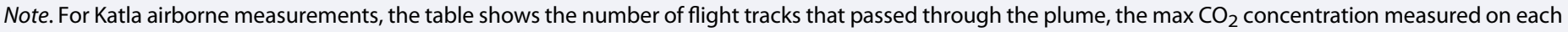
flight, and the altitude at which the $\mathrm{CO}_{2}$ plume was found. Methods used for Katla $\mathrm{CO}_{2}$ flux calculations: IDW, inverse distance weighting; Gaussian, fitting of a Gaussian plume dispersion model; SMF, specified mass flux.

Pálmason et al., 1985), are poorly constrained and are likely too low (Ármannsson et al., 2005). The $\mathrm{CO}_{2}$ flux from Grímsvötn and Eyjafjallajökull were estimated by analyzing gas content dissolved in melt water accumulating under the ice that likely underestimates the flux as $\mathrm{CO}_{2}$ degasses very rapidly when the water is depressurized. Our study is the first to report the $\mathrm{CO}_{2}$ flux from a subglacial volcano in Iceland by measuring the gas directly in the atmosphere.

Measurements of gas emissions from subglacial volcanic systems are important for understanding the underlying magma systems and, subsequently, for forecasting their eruptions, which are typically highly hazardous due to the generation of ash and jökulhlaups (flash floods of glacial melt water). Recent studies across different tectonic and geographical settings have demonstrated that increases in $\mathrm{CO}_{2}$ output can precede eruptions by months to years, for example, at Redoubt in the Aleutians (Werner et al., 2012), Kilauea in Hawaii (Poland et al., 2012), and Villarica in Chile (Aiuppa et al., 2017) but it is not yet known if this applies to any of the Icelandic volcanoes.

\subsection{Katla Volcanic System}

The subglacial Katla volcanic system is one of the largest and most active ones in Iceland and has erupted 1-3 times per century since the settlement of Iceland 1,100 years ago (Larsen, 2000), and up to 6 times per century in prehistoric times (Óladóttir et al., 2008). The current repose period is the longest one on record, with the last confirmed eruption in 1918 C.E. Katla system consists of a central volcano (max altitude $1,500 \mathrm{~m}$ above sea level [asl]) and $80-\mathrm{km}$ long fissure system. The central volcano is partially covered by the vast $590-\mathrm{km}^{2}$ Mýrdalsjökull glacier, which is on average $200 \mathrm{~m}$ thick, reaching $700-\mathrm{m}$ thickness in 


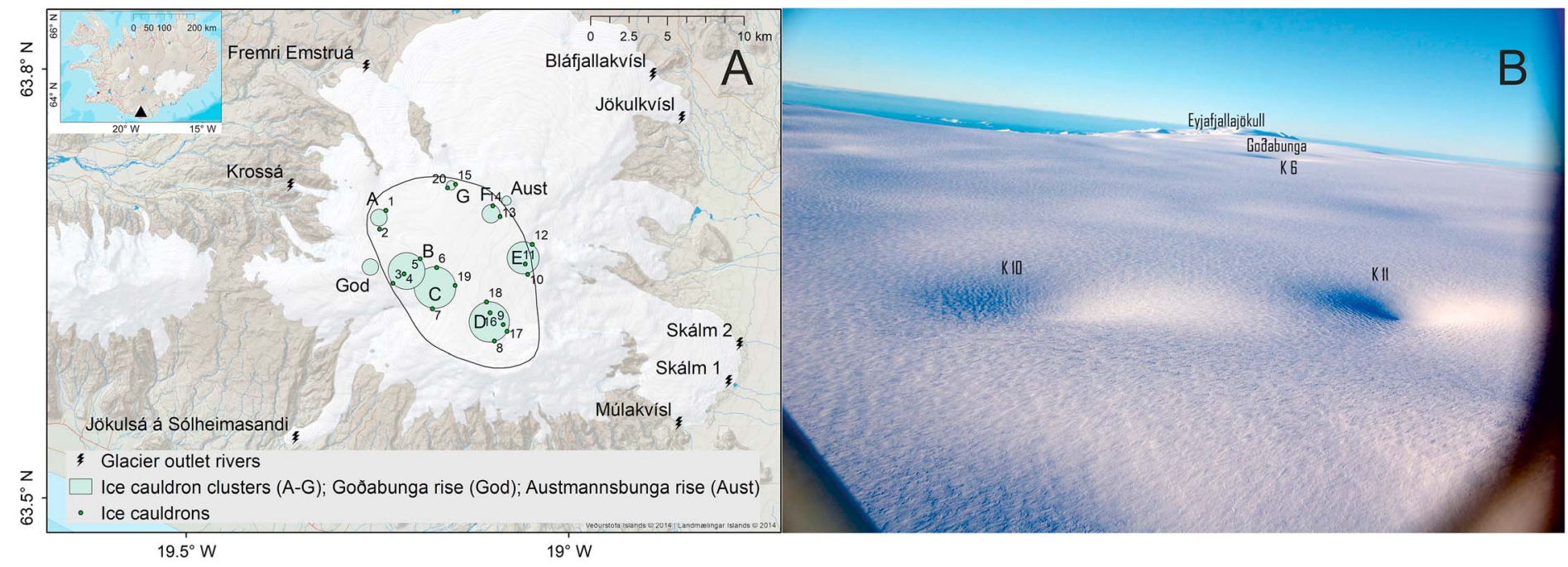

Figure 1. (a) Map and (b) photograph of Katla. The map shows the outlines of the subglacial caldera and locations of glacier river outlets $(n=8)$, ice cauldrons $(n=20)$, Goðabunga rise (God), and Austmannsbunga rise (Aust). For model simulations of the gas source, the 20 ice cauldrons were combined into seven clusters (A-G). The photograph, taken in November 2017, shows ice cauldrons 10 and 11 (K10 and K11, respectively) and Goðabunga rise. The cauldrons are several hundreds of meters in diameter. The summit of the neighboring Eyjafjalljökull volcano is seen behind the Katla caldera.

places. The central volcano contains a large, ice-filled caldera $\left(110 \mathrm{~km}^{2}\right.$, Figure 1$)$. The eruptions within the glaciated part are typically accompanied by tephra generation (bulk volume $0.02-2 \mathrm{~km}^{3}$ ) and jökulhlaups due to the magma-ice interaction (Larsen, 2000). The fissure swarm has produced large effusive basaltic eruptions with lava volumes $\geq 18 \mathrm{~km}^{3}$ (Thordarson et al., 2003). The size and proximity to populations of Katla mean that the next eruption will likely have major local and possibly regional impacts, whether it occurs within the glaciated or nonglaciated part of the system. Disturbance to international aviation by ash is likely, even if the eruption is small in size (Biass et al., 2014).

Katla has had recurring geophysical unrest (seismicity and ground deformation), but the presence of glacial ice makes the subsurface signals difficult to interpret. Previous studies have disagreed on whether unrest in different parts of the system is caused by movements of magma (e.g., Soosalu et al., 2006; Sturkell et al., 2008), or movements of glacial ice and its seasonal changes (e.g., Jónsdóttir et al., 2009; Spaans et al., 2015). Katla has an annual average of $\sim 300$ earthquakes (Icelandic Met Office monitoring data) and periodic escalations of up to a few thousand earthquakes. The majority of the earthquakes are at 0 - to $5-\mathrm{km}$ depth and $<2.5$ in magnitude, with rarer occurrences of deeper (up to 20-km depth) and larger events (magnitude $\geq 4$ ). There are two main areas of geophysical unrest - within the caldera, and near the Godabunga rise on the western part of the central volcano (e.g., Jónsdóttir et al., 2009). The largest unrest periods since the last confirmed eruption have occurred in 1955, 1999, and 2011 C.E. These periods had increased seismicity for months to years, increased geothermal activity, and significant jökulhlaups that caused damage to infrastructure (Sturkell et al., 2008). It has not been conclusively shown whether these episodes were associated with small subglacial eruptions.

Katla has no obvious degassing vents or areas, or visible gas plumes. Presence of subglacial activity is manifested by 20 ice cauldrons, which are 10- to 50-m deep depressions in the glacier surface (Figure 1) caused by geothermal melting of the glacier base. Geothermal melt water escapes through the glacier drainage systems and is periodically flushed out from the outlet rivers (Figure 1). The number, size, and shape of Katla's ice cauldrons and the activity of the outlet rivers change over time as the subglacial system is highly dynamic (Guðmundsson et al., 2007), likely influenced both by the state of the volcanic system, and short- and long-term variations in weather and climate. The smell of hydrogen sulfide $\left(\mathrm{H}_{2} \mathrm{~S}\right)$ is commonly reported near the outlet rivers, in particular during major and minor jökulhlaups (Bergsson, 2016). Conversely, there are no known reports of visible gas plumes or gas smell in the vicinity of the ice cauldrons. A DOAS UV spectrometer installed on the flanks of Katla since July 2017 has never detected sulfur dioxide $\left(\mathrm{SO}_{2}\right)$ (Icelandic Met Office monitoring data).

The only eruption of Katla where gas release has been estimated using the petrological method is the Eldgjá flood basalt eruption 934-40 C.E. (Thordarson et al., 2003). Its current gas emission rate has not been 
quantified. Here we measured Katla's gas emissions from an aircraft in October 2016 and October 2017. This work builds on previous airborne measurements of $\mathrm{CO}_{2}$-rich plumes in other countries using in situ sensors (Delgado et al., 1998; Doukas \& McGee, 2007; Gerlach et al., 1999, 1997; Werner et al., 2006, 2008, 2012, 2013) and serves as a proof-of-concept for monitoring gas emissions from other Icelandic volcanic systems.

\section{Methods}

\subsection{Airborne Observations}

The airborne observations were made using the atmospheric research aircraft (a highly modified BAE-146 aircraft) of the Facility for Airborne Atmospheric Measurements (http://www.faam.ac.uk). Details about the instrumentation are in Text S1 in the supporting information. Flight paths were selected based on the prevalent wind direction in order to obtain downwind measurements of active volcanoes. Low-altitude cloud distribution and topography influenced the flight path planning for safety reasons. No flights traversing the subglacial caldera were possible in 2016 or 2017 due to cloud cover over the glacier. The full tracks of the flights reported in this paper are shown in Figure S1 in the supporting information.

\subsection{Gas Source Modeling}

In order to identify the source of the excess $\mathrm{CO}_{2}$, we applied two approaches. The first was to use backtrajectories based on simple, low-resolution forecast wind fields; we used the Hybrid Single-Particle Lagrangian Integrated Trajectory (HYSPLIT) Lagrangian dispersion model driven by GFS forecast winds (full details about the model in Text S1). The second involved simulating the effects of a variety of plausible sources within a very high resolution numerical weather prediction model (Weather Research and Forecasting model [WRF]; full details about the model Text S1) and comparing the distribution of dispersed gases within the model with the observations. HYSPLIT was run from numerous measurement points along the aircraft track for $12 \mathrm{hr}$ back in time in order to determine which trajectories coincided with likely sources. The relatively long run time was chosen so that there were no initial constraints on the gas source within Iceland (e.g., other volcanic systems and anthropogenic activities). Results of HYSPLIT are included in supporting information (Figure S2). For the sources in the WRF simulations we initially used the 32 volcanic systems in Iceland (Figure S1) and ran the WRF model with $\mathrm{CO}_{2}$ as a passive tracer. This confirmed unequivocally that the source was in the region of Katla, leading us to make further measurement flights in 2017, and more detailed simulations of the Katla region in order to identify the source of the gas. For these simulations, we specified as potential sources 8 glacier outlet rivers from Katla, 20 ice cauldrons within the caldera that were combined into 7 cauldron clusters (A-G), and Goðabunga rise (a location of long-term seismic activity on the volcano's west flank), giving a total of 16 sources (Figure 1). All sources were treated as a point release of a dense gas with a specified emission rate (full details in Text S1). For most of the simulated cases, HYSPLIT and WRF indicated the same source locations; notable differences are described in section 3.

\subsection{Gas Emission Rate Calculations}

As the exact location and number of the degassing sources within the large glacier $\left(590 \mathrm{~km}^{2}\right)$ overlying Katla were unknown, the calculation of the $\mathrm{CO}_{2}$ emission rate ("flux") presented a challenge not previously reported in studies using airborne measurements. We calculated the $\mathrm{CO}_{2}$ flux using two independent methods, direct calculations and model simulations. The model simulations provided an independent means of mass flux estimation and hence a corroboration of the principal findings of the paper.

The first method was a direct calculation of the measured mass flux by integration of interpolations of the measured wind and $\mathrm{CO}_{2}$ concentration fields (we used two different interpolation techniques). The interpolation techniques were inverse distance weighting (IDW in Table 1) for all of the flights and fitting of a Gaussian plume dispersion model (Gaussian in Table 1). The Gaussian method provided an independent flux estimate in addition to IDW. Several restrictions on its use (the requirement for a Gaussian plume, the need for wind speeds above $5 \mathrm{~m} / \mathrm{s}$, and the wind direction and flight track alignment to be perpendicular) meant that the Gaussian method could only be used for flight B989 (Table 1). It is included here for completeness. See Text S1 for further details about both interpolation techniques.

Motivated by the large emission rates given by IDW and Gaussian calculations (11-20 kt/d of $\mathrm{CO}_{2}$, Table 1), we designed the second method of estimating emission rates using a state-of-the-art numerical model, WRF (the 
simulations described in section 2.2). WRF is able to resolve the complex, unsteady flows associated with such a topographically complex region. Coupled with dense gas dynamics, WRF is essential here for effective source identification. Additionally, the use of WRF enabled various emission scenarios to be tested, adjusting the source strength to maximize correlation between observed and modeled $\mathrm{CO}_{2}$ concentrations along the aircraft tracks (specified mass flux in Table 1). See Text S1 for further details.

Agreement between the different methods in this challenging degassing scenario provided additional confidence that assumptions concerning the dispersion mechanisms were sound and that the measurements were representative of the gas plumes.

\section{Results and Discussion}

\subsection{Katla as a Source of Elevated $\mathrm{CO}_{2}$}

Gas plumes of elevated $\mathrm{CO}_{2}$ were detected on three airborne measurement campaigns at Katla, on 18 October 2016 (flight number B987), 20 October 2016 (B989), and 4 October 2017 (C060). Background concentrations of $\mathrm{CO}_{2}$ were around $400 \mathrm{ppm} . \mathrm{CO}_{2}$ concentrations exceeding background levels up to $32 \mathrm{ppm}$ were detected in the immediate vicinity of Katla (Figures 2a, 2c, and 2e) and up to 8-15 ppm in excess of background $\sim 80 \mathrm{~km}$ to the east of it (B987 only, Figure 2e). Significant anthropogenic sources of $\mathrm{CO}_{2}$ are highly unlikely upwind of the areas where the elevated concentrations were observed. $\mathrm{H}_{2} \mathrm{~S}$ smell was noticed in the aircraft cabin on several flights, both to the south and north of the glacier, but instrumental measurements were not obtained (see Text $\mathrm{S} 1$ for further details). $\mathrm{SO}_{2}$ was below the 3-sigma detection limit of the fluorescence photometer of $1.5 \mathrm{ppb}$ for 1-s measurements. The $\mathrm{CO}_{2} / \mathrm{CH}_{4}$ ratio in the gas plumes was 200 ( $r^{2}$ between 0.81 and 0.99 , Figure 2$)$; this gas composition suggests an interaction with a geothermal system in the roots of the subglacial caldera (Chiodini, 2009). This $\mathrm{CO}_{2} / \mathrm{CH}_{4}$ ratio is very similar to the ratios measured in fumarole direct samples from other Icelandic volcanoes that are primarily ice-capped (Kverkfjöll: 200, Grímsvötn, 300-350; Icelandic Met Office monitoring data). We first describe and discuss the results of 20 October 2016 (flight B989) and 4 October 2017 (C060), followed by 18 October 2016 (B987), which had a more complex gas dispersal pattern than the first two.

On 20 October 2016 (B989) the airborne measurements detected a well-defined $\mathrm{CO}_{2}$ plume with maximum concentration of $413 \mathrm{ppm}$ ( $13 \mathrm{ppm}$ above background) to the north of the Katla glacier at an altitude between 840 and 1,200 $\mathrm{m}$ asl (Figure 2a). The edge of the glacier is at $\sim 500 \mathrm{~m}$ asl, and it then rises fairly steeply towards the middle of the caldera, the floor of which is at $\sim 1,400-1,500 \mathrm{~m}$ asl. Model simulations emitting 5-10 kt/d of $\mathrm{CO}_{2}$ identified that the likely source of excess $\mathrm{CO}_{2}$ was on the western flank of Katla volcano where two outlet rivers (Fremri-Emstruá and Krossá, $500 \mathrm{~m}$ asl) and Goðabunga rise (1,500 $\mathrm{m}$ asl) are located. Ice cauldron cluster A ( 1,500 m asl) on the western edge of the caldera is also a possible source (Figure 2b). We consider that the outlet rivers are possible sources of the $\mathrm{CO}_{2}$ even when the flight tracks passed above the rivers. The $\mathrm{CO}_{2}$ concentrations of up to $\sim 30 \mathrm{ppm}$ above background represent a small fraction of the background air and are unlikely to restrict the vertical motion associated with very complex underlying topography (Figure 3).

On 4 October 2017 (C060) elevated $\mathrm{CO}_{2}$ concentrations were measured in two locations, as two separate and well-defined gas plumes. The first gas plume was to the northwest of Katla (up to 432 ppm, 890-970 m asl, Figure 2c) and could be reproduced by the model when 5-10 kt/d of $\mathrm{CO}_{2}$ was released from FremriEmstruá River on the western flank of Katla (Figure 2d), which is in good agreement with B989. The second plume was to the southeast of Katla (up to 415 ppm, 380-650 m asl, Figure 2c) and was reproduced with 5- to 10-kt/d emission rate when the gas was emitted from ice cauldron clusters $\mathrm{E}, \mathrm{F}$, or $\mathrm{G}$ within the caldera (Figure 2d). Cauldron cluster E contains two of the currently most active ice cauldrons (Guðmundsson et al., 2007), $\mathrm{nr} 10$ and 11. This source area also includes a nunatak (elevated bedrock exposed within a glacier) named Austmannsbunga, 1,400 m asl, a location of frequent current seismic unrest and surface deformation (Icelandic Met Office monitoring data).

On 18 October 2016 (B987) elevated $\mathrm{CO}_{2}$ concentrations (up to 432 ppm) were measured immediately to the southeast of Katla at altitude 100-600 m asl (Figure 2e), at a similar location and altitude to that detected by C060. Elevated $\mathrm{CO}_{2}$ (up to $409 \mathrm{ppm}$ ) was also measured in the coastal regions $\sim 80 \mathrm{~km}$ to the east of Katla at altitudes between 200 and 1,600 m asl, with the highest values (408-409 ppm) between 210 and $540 \mathrm{~m}$ asl 

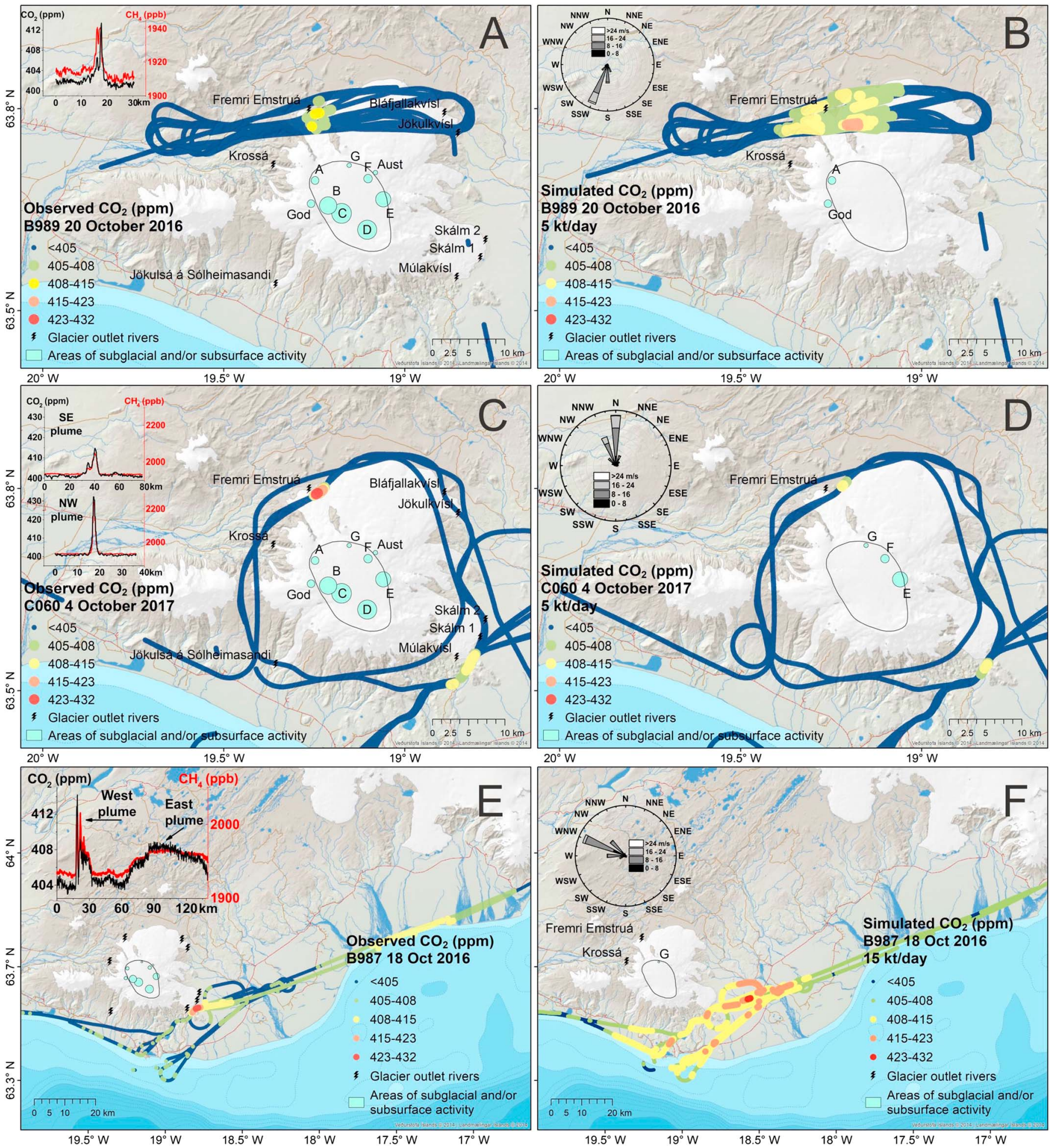

Figure 2. Observed and simulated $\mathrm{CO}_{2}$ plumes from Katla volcano on 18 and 20 October 2016 and 4 October 2017. The panels show the wind direction and speed measured during each flight and along-track points of $\mathrm{CO}_{2}$ and $\mathrm{CH}_{4}$ concentrations. (a) Observed $\mathrm{CO}_{2}$ peak on 20 Oct 2016 (flight B989). (b) The best-fit simulated sources for the $\mathrm{CO}_{2}$ peak observed on 20 Oct 2016: rivers Fremri Emstruá and Krossá, ice cauldron cluster A, and Goðabunda rise. The figure shows simulation of $5 \mathrm{kt} / \mathrm{d}$ of $\mathrm{CO}_{2}$, but good agreement was also reached with $10 \mathrm{kt} / \mathrm{d}$. (c) Two observed $\mathrm{CO}_{2}$ peaks on 4 Oct 2017 (flight C060), to the northwest (NW) and southeast (SE) of the caldera. (d) The best-fit simulated sources for the $\mathrm{CO}_{2}$ peaks observed on 4 Oct 2017: river Fremri Emstruá and ice cauldron clusters $\mathrm{E}, \mathrm{F}$ and $\mathrm{G}$. The figure shows simulation of $5 \mathrm{kt} / \mathrm{d}$ of $\mathrm{CO}_{2}$, but good agreement was also reached with $10 \mathrm{kt} / \mathrm{d}$. (e) Two observed $\mathrm{CO}_{2}$ peaks on $18 \mathrm{Oct} 2016$ (flight B987), to the west and east of the caldera. ( $f$ ) The best-fit simulated sources for the $\mathrm{CO}_{2}$ peaks observed on 18 Oct 2016-rivers Fremri Emstruá and Krossá and ice cauldron cluster $\mathrm{G}$. Both of the observed $\mathrm{CO}_{2}$ peaks can be traced to Katla when $\mathrm{CO}_{2}$ is simulated as a dense gas with emission rate of $15 \mathrm{kt} / \mathrm{d}$. 

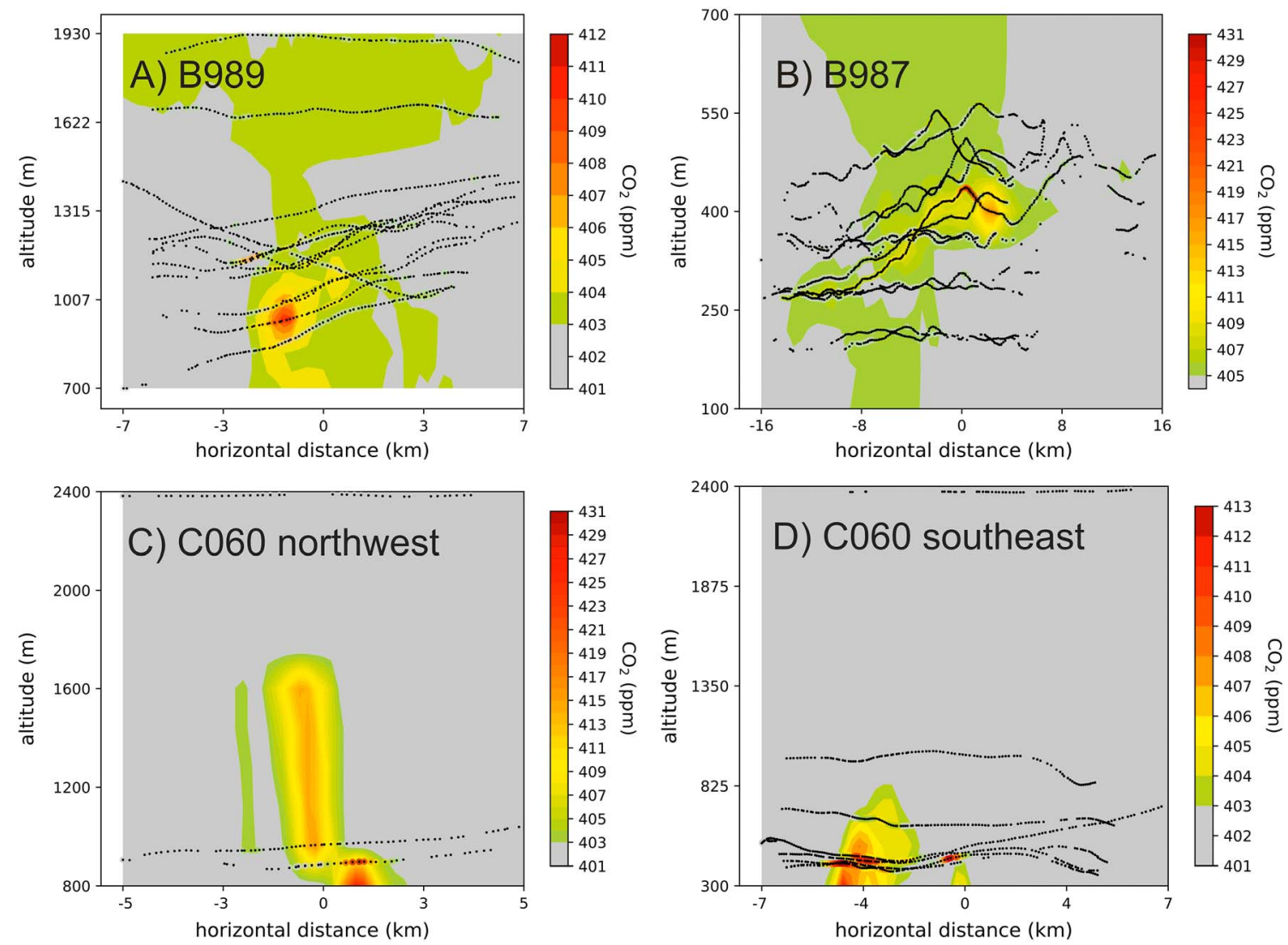

Figure 3. Vertical cross section through the interpolated $\mathrm{CO}_{2}$ gas plumes from flights (a) B989 (20 October 2016); (b) B987 (18 October 2016 ), and C060 (4 October 2017), which intersected two gas plumes in 2 locations; (c) to the northwest of Katla; and from (d) to the southeast of Katla. The black dots show the measurement locations on the flight tracks. The $x$ axis represents the horizontal distance from the center of the plume (the location with the highest measured gas concentration). The flight paths close to ground level $(<1,500 \mathrm{~m}$ above sea level) were influenced by the highly irregular mountainous topography.

(Figure 2e). Dense gas simulations, emitting $15 \mathrm{kt} / \mathrm{d}$ of $\mathrm{CO}_{2}$, were able to trace the gas observed to the east of Katla when Fremri-Emstruá and Krossá Rivers were considered as sources (Figure 2f), with the gas flowing through and accumulating in valleys. Ice cauldron cluster $G$ was also a possible source (Figure 2f). However the simulated concentrations were much lower (of the order of $0.1 \mathrm{ppm}$ above background) than observed. This may be caused by gas accumulating over a longer time period than the duration of the simulation, or the existence of a possible extra source not accounted for here. Flight B987 is a notable example of the complexity (fine-scale variability and unsteadiness) of the air flow around a volcanic edifice. Simple models (e.g., HYSPLIT) cannot be used for source identification in such circumstances. Further observations coupled with model simulations would be required to understand scenarios such as B987 better.

The relatively well-defined structure of the gas plumes (Figure 3) suggests that the degassing source(s) within the Katla volcanic system are focused rather than diffuse, and we have made used model simulations to show that these sources could be located on the western flank of Katla, and within the central caldera (Figure 2). However, more detailed observations, ground- and/or airborne, will be needed to determine the location(s) of the gas source with more accuracy. It is likely that the gas source location(s) are dynamic in this subglacial volcanic environment and change over time.

\section{2. $\mathrm{CO}_{2}$ Emission Rate From Katla}

Emission rate calculations (section 2.3) showed that a source associated with the western side of Katla (see Figure 2 for likely source locations) was emitting 11.9-19.6 kt/d of $\mathrm{CO}_{2}$ in October 2016 and $12.8 \mathrm{kt} / \mathrm{d}$ in October 2017 (Table 1). In 2017, we were able to identify a second source of $\mathrm{CO}_{2}$ (Table 1) most likely within the caldera, emitting $11.4 \mathrm{kt} / \mathrm{d}$ (best-fit sources ice cauldron clusters E, F and G in Figure $2 \mathrm{~d}$ ), although the low 
number of flight passes through this plume gives a lower confidence in the flux calculation than for the other flights (Figure 3 and Table 1). It is possible that there was no significant degassing from within the caldera in 2016, as the gas fluxes and exit paths are likely to be unstable in this highly dynamic volcanic-glacial system; the emission rate from $2016(12-20 \mathrm{kt} / \mathrm{d}$ ) is compatible with the total emission rate (flank + caldera) from 2017 (13-24 kt/d). Emission rate of 12-24 kt/d is significant on a global level. Table 1 compares the Katla fluxes to other volcanic sources in Iceland. In Iceland, the previous estimates of total natural $\mathrm{CO}_{2}$ flux amounted to $2.7-5.8 \mathrm{kt} / \mathrm{d}$ (Ármannsson et al., 2005) and included emissions from only four volcanic systems (Grímsvötn, Eyjafjallajökull, Hekla, and Krafla). The emissions from Katla (12-24 kt/d) are therefore at least double the previous estimates of total natural $\mathrm{CO}_{2}$ from Iceland. Compared to the top global volcanic $\mathrm{CO}_{2}$ emitters, Katla is one of the top three, potentially exceeded only by Nyiragongo (1-95 kt/d, Arellano et al., 2017, Le Guern, 1987) and Popocatéptl (9-40 kt/d, Gerlach et al., 1997, Delgado et al., 1998).

It should not be assumed that this airborne study has captured all the $\mathrm{CO}_{2}$ sources from Katla under all conditions. For example, $\mathrm{CO}_{2}$ emission has also been detected near several other outlet rivers by ground-based gas sensors (Icelandic Met Office monitoring data). These measurements are ill-suited to determining the total flux of $\mathrm{CO}_{2}$ being released, nor are they suitable for determining the maximum concentrations of $\mathrm{CO}_{2}$ released, as this would need to be measured at the mouth of the outlet river, an unstable, dynamic environment where permanent installations are unsustainable. We share these results here to show that there are additional, noncontinuous, ground-level emissions of $\mathrm{CO}_{2}$ from Katla volcano that may not be captured in our aircraft-based assessment. Ground-based $\mathrm{CO}_{2}$ concentration measurements during a jökulhlaup were made at the outlet river Jökulsá á Sólheimasandi in July 2014, with values of up to 12,000-ppm $\mathrm{CO}_{2}$. These measurements did not start until after the peak of the flood. Measurements were also made during small jökulhlaups at the outlet river Múlakvísl in August 2016 (concentration in excess of 1,400 ppm) and November 2017 (concentration in excess of 4,000 ppm). These ground-based observations demonstrate that at least during flooding events, additional $\mathrm{CO}_{2}$ sources exist at Katla.

Studies from Kilauea (Poland et al., 2012) and Redoubt volcanoes (Werner et al., 2012) showed that increases in $\mathrm{CO}_{2}$ flux of up to $10-20 \mathrm{kt} / \mathrm{d}$ may precede eruptive activity by weeks to months. It is not yet known if Katla's large degassing rate is part of its steady state, or if it has been increasing recently. The depth of the degassing is also unknown; basaltic melts can become saturated in $\mathrm{CO}_{2}$ at tens of kilometer depths. We estimate the lower and upper limits of the mass of magma degassing per day required to sustain the fluxes we observed using magmatic $\mathrm{CO}_{2}$ contents measured in recent basaltic eruptions in Iceland (no data are available for Katla): 0.14 wt \% from Holuhraun 2014-2015 (lower limit, Bali et al., 2018) and 1.1 wt \% $\mathrm{CO}_{2}$ from Fimmvörðuháls 2010 (upper limit, Burton et al., 2015). Using the lower limit of the observed $\mathrm{CO}_{2}$ flux of $12 \mathrm{kt} /$ day the required minimum magma mass flux (assuming $1.1 \mathrm{wt} \% \mathrm{CO}_{2}$ ) is $0.18 \mathrm{~km}^{3}$ per year. If the lower limit of $0.1 \mathrm{wt} \%$ is assumed, the volume of magma increases by an order of magnitude ( $1.8 \mathrm{~km}^{3}$ per year). Further ground deformation studies at Katla are recommended to shed light on the volumes suggested by the gas measurements.

\section{Conclusions}

The discovery of a very large $\mathrm{CO}_{2}$ emission from Katla volcano is novel, as Katla was thought to be a minor emitter of gases between the periodic jökulhlaups and eruptions (last eruption in 1918 C.E.). We have shown unequivocally that Katla volcanic system as a whole is a source of $\mathrm{CO}_{2}$, but the exact location(s) of the degassing sources is still unknown (and are potentially dynamic). Using model simulations, we have made an attempt to show that the degassing sources are likely to be located on the western flank and within the central Katla caldera. However, further direct observations are needed to locate these sources with greater accuracy.

The globally significant $\mathrm{CO}_{2}$ emission from Katla may indicate that this volcanic system is supplied by magmatic gas from depth and that the ongoing geophysical unrest in Katla is due to magma movements. It is not yet known if this is Katla's steady-state or if the gas flux is changing. The collection of a $\mathrm{CO}_{2}$ flux time series and measurements of other gas species, including, for example, hydrogen sulfide and methane, will therefore be critical for furthering our understanding. Regular gas measurements, airborne and/or ground-based, should be established as part of routine monitoring at this highly active and hazardous volcano. 


\section{Acknowledgments}

This work was funded by NERC grant Volcanic and Atmospheric Near- to farfield Analysis of plumes Helping Interpretation and Modeling (NE/ 101554X/1). The research has also received funding from the European Research Council under the European Union's Seventh Framework Programme (FP/2007-2013)/ERC grant agreements 30877 (Futurevolc) and $279802\left(\mathrm{CO}_{2}\right.$ Volc). The continuous DOAS monitoring of Katla is supported by a grant from the Nordic Council of Ministers' Climate and Air Pollution Group, KOL-1607. Reynir Ragnarsson is acknowledged for the photograph in Figure $1 \mathrm{~b}$. Cynthia Werner and Alessandro Aiuppa are thanked for thorough and helpful suggestions for improvements to the manuscript. The data are available from the British Atmospheric Data Centre (BADC) repository http://artefacts.ceda.ac.uk/ badc datadocs/index test.html.
It is not known how representative Katla may be of other subglacial volcanoes, in Iceland or globally. A global total volcanic $\mathrm{CO}_{2}$ flux from passively degassing subaerial volcanoes was estimated at $540 \mathrm{kt} / \mathrm{d}$ (Burton et al. 2013) based on extrapolation of $\mathrm{CO}_{2}$ flux measurements from 33 volcanoes to an estimated 150 volcanoes (Global Volcanism Program, 2013). Only 3 of the measured 33 volcanoes were subglacial (Redoubt, Spurr, and Grímsvötn). In comparison, our measurements of $\mathrm{CO}_{2}$ flux from Katla represent around 2-4\% of this total. If degassing from subglacial volcanoes occurs widely on the same scale as Katla, then the total contribution from subglacial volcanoes would change the global $\mathrm{CO}_{2}$ degassing estimate very significantly. However, the size and relatively recent activity of Katla may make it an exceptional emitter; this will remain an open question until similar measurements can be made on more subglacial volcanoes. We conclude that further airborne measurements using sensitive gas sensors are urgently required, targeted on subglacial volcanoes to establish if Katla volcanism is the exception, or the rule.

\section{References}

Ágústsdóttir, A. M., \& Brantley, S. L. (1994). Volatile fluxes integrated over four decades at Grímsvötn volcano, Iceland. Journal of Geophysical Research, 99(B5), 9505-9522. https://doi.org/10.1029/93JB03597

Aiuppa, A., Bitetto, M., Francofonte, V., Velasquez, G., Parra, C. B., Giudice, G., et al. (2017). A CO2-gas precursor to the March 2015 Villarrica volcano eruption. Geochemistry, Geophysics, Geosystems, 18, 2120-2132. https://doi.org/10.1002/2017GC006892

Arellano, S., Yalire, M., Galle, B., Bobrowski, N., Dingwell, A., Johansson, M., et al. (2017). Long-term monitoring of SO2 quiescent degassing from Nyiragongo's lava lake. Journal of African Earth Sciences, 134, 866-873. https://doi.org/10.1016/j.jafrearsci.2016.07.002

Ármannsson, H., Fridriksson, T., \& Kristjánsson, B. R. (2005). CO2 emissions from geothermal power plants and natural geothermal activity in Iceland. Geothermics, 34(3), 286-296. https://doi.org/10.1016/j.geothermics.2004.11.005

Ármannsson, H., Fridriksson, T., Wiese, F., Hernandez, P., \& Perez, N. (2007). CO2 budget of the Krafla geothermal system, NE-Iceland, in: Proceedings of the 12th International Symposium on Water-Rock Interaction 2007 (pp. 189-192). London: Taylor \& Francis Group.

Arnórsson, S., \& Gislason, S. R. (1994). CO2 from magmatic sources in Iceland. Mineralogical Magazine, 58A(1), 27-28. https://doi.org/10.1180/ minmag.1994.58A.1.17

Bali, E., Hartley, M. E., Halldórsson, S. A., Gudfinnsson, G. H., \& Jakobsson, S. (2018). Melt inclusion constraints on volatile systematics and degassing history of the 2014-2015 Holuhraun eruption, Iceland. Contributions to Mineralogy and Petrology, 173, 9. https://doi.org/ 10.1007/s00410-017-1434-1

Bergsson, B. (2016). Volcanogenic floods at Sólheimajökull. Hazard identification, monitoring and mitigation of future events, (Master's thesis, 97 pp.). Faculty of Life and Environmental sciences, University of Iceland, Reykjavik.

Biass, S., Scaini, C., Bonadonna, C., Folch, A., Smith, K., \& Höskuldsson, A. (2014). A multi-scale risk assessment for tephra fallout and airborne concentration from multiple Icelandic volcanoes-Part 1: Hazard assessment. Natural Hazards and Earth System Sciences, 14(8), 2265-2287. https://doi.org/10.5194/nhess-14-2265-2014

Burton, M., Ilyinskaya, E., La Spina, A., Salerno, G., Bergsson, B., Donovan, A., et al. (2015). Contrasting gas compositions and fluxes produced by the Holuhraun 2014/2015 eruption and the Fimmvörðuháls 2010 eruption, Iceland. Geophysical Research Abstracts, 17, EGU2015-15899. Retrieved from http://meetingorganizer.copernicus.org/EGU2015/EGU2015-15899.pdf

Burton, M. R., Sawyer, G. M., \& Granieri, D. (2013). Deep carbon emissions from volcanoes. Reviews in Mineralogy and Geochemistry, 75(1), 323-354. https://doi.org/10.2138/rmg.2013.75.11

Chiodini, G. (2009). CO2/CH4 ratio in fumaroles a powerful tool to detect magma degassing episodes at quiescent volcanoes. Geophysical Research Letters, 36, L02302. https://doi.org/10.1029/2008GL036347

Delgado, H., Piedad-Sanchez, N., Galvan, L., Julio, T., Alvarez, M., \& Cardenas, L. (1998). CO2 flux measurements at Popocatepetl volcano: II magnitude of emissions and significance. EOS TransSupplement, 79, F926.

Doukas, M. P., \& McGee, K. A. (2007). A compilation of gas emission-rate data from volcanoes of Cook Inlet (Spurr, Crater Peak, Redoubt, Iliamna, and Augustine) and Alaska Peninsula (Douglas, Fourpeaked, Griggs, Mageik, Martin, Peulik, Ukinrek Maars, and Veniaminof), Alaska, from 1995-2006 (USGS Numbered Series No. 2007-1400), Open-File Report. Geological Survey (U.S.).

Fridriksson, T., Kristjansson, B. R., Armannsson, H., Margretardottir, E., Olafsdottir, S., \& Chiodini, G. (2006). CO2 emissions and heat flow through soil, fumaroles, and steam heated mud pools at the Reykjanes geothermal area, SW Iceland. Applied Geochemistry, 21(9), 1551-1569. https://doi.org/10.1016/j.apgeochem.2006.04.006

Fridriksson, T., Oladottir, A. A., Jonsson, P., \& Eyjolfsdottir, E. I. (2010). The response of the Reykjanes geothermal system to $100 \mathrm{MWe}$ powe production: Fluid chemistry and surface activity. In Proceedings World Geothermal Congress. Bali, Indonesia.

Friedlingstein, P., Houghton, R. A., Marland, G., Hackler, J., Boden, T. A., Conway, T. J., et al. (2010). Update on $\mathrm{CO}_{2}$ emissions. Nature Geoscience, 3(12), 811-812. https://doi.org/10.1038/ngeo1022

Gerlach, T. M., Doukas, M. P., McGee, K. A., \& Kessler, R. (1999). Airborne detection of diffuse carbon dioxide emissions at Mammoth Mountain, California. Geophysical Research Letters, 26(24), 3661-3664. https://doi.org/10.1029/1999GL008388

Gerlach, T. M., McGee, K. A., Elias, T., Sutton, A. J., \& Doukas, M. P. (1997). Application of the LI-COR CO2 analyzer to volcanic plumes: A case study, volcán Popocatépetl, Mexico, June 7 and 10, 1995. Journal of Geophysical Research, 102(B4), 8005-8019. https://doi.org/10.1029/ 96JB03887

Gíslason, S. (2000). Carbon dioxide from Eyjafjallajökull and chemical composition of spring water and river water in the EyjafjalljökullMýrdalsjökull region (no. RH-06-2000). Science Institute, University of Iceland.

Gislason, S. R., Andrésdóttir, A., Sveinbjörnsdóttir, Á., Oskarsson, N., Thordarson, T., Torssander, P., et al. (1992). Local effects of volcanoes on the hydrosphere: Example from Hekla, southern Iceland. Water-rock interact. Rotterdam Balkema, 1, 477-481.

Global Volcanism Program (2013). Volcanoes of the World, v. 4.7.3. Venzke, E (ed.). Smithsonian Institution. Downloaded 7 Sep 2018. https:// doi.org/10.5479/si.GVP.VOTW4-2013

Guðmundsson, M., Högnadóttir, P., Kristinsson, A., \& Guðbjörnsson, S. (2007). Geothermal activity in the subglacial Katla caldera, Iceland 1999-2005, studied with radar altimetry. Annals of Glaciology, 45, 66-72. https://doi.org/10.3189/172756407782282444

Hernández, P., Pérez, N., Fridriksson, T., Egbert, J., llyinskaya, E., Thárhallsson, A., et al. (2012). Diffuse volcanic degassing and thermal energy release from Hengill volcanic system, Iceland. Bulletin of Volcanology, 74(10), 2435-2448. https://doi.org/10.1007/s00445-012-0673-2 
Ilyinskaya, E., Aiuppa, A., Bergsson, B., Di Napoli, R., Fridriksson, T., Óladóttir, A. A., et al. (2015). Degassing regime of Hekla volcano $2012-2013$. Geochimica et Cosmochimica Acta, 159, 80-99. https://doi.org/10.1016/j.gca.2015.01.013

Jónsdóttir, K., Roberts, R., Pohjola, V., Lund, B., Shomali, Z. H., Tryggvason, A., et al. (2009). Glacial long period seismic events at Katla volcano, Iceland. Geophysical Research Letters, 36, L11402. https://doi.org/10.1029/2009GL038234

Larsen, G. (2000). Holocene eruptions within the Katla volcanic system, south Iceland: Characteristics and environmental impact. Jökull, 49, 1.

Le Guern, F. (1987). Mechanism of energy transfer in the lava lake of Niragongo (Zaire), 1959-1977. Journal of Volcanology and Geothermal Research, 31(1-2), 17-31. https://doi.org/10.1016/0377-0273(87)90003-5

Óladóttir, B. A., Sigmarsson, O., Larsen, G., \& Thordarson, T. (2008). Katla volcano, Iceland: Magma composition, dynamics and eruption frequency as recorded by Holocene tephra layers. Bulletin of Volcanology, 70(4), 475-493. https://doi.org/10.1007/s00445-007-0150-5

Pálmason, G., Johnsen, G. V., Torfason, H., Sæmundsson, K., Ragnars, K., Haraldsson, G. I., et al. (1985). Assessment of geothermal energy in Iceland (no. OS-85076/JHD-10). Orkustofnun.

Poland, M. P., Miklius, A., Sutton, A. J., \& Thornber, C. R. (2012). A mantle-driven surge in magma supply to Kïlauea volcano during $2003-2007$. Nature Geoscience, 5(4), 295-300. https://doi.org/10.1038/ngeo1426

Soosalu, H., Jónsdóttir, K., \& Einarsson, P. (2006). Seismicity crisis at the Katla volcano, Iceland-Signs of a cryptodome? Journal of Volcanology and Geothermal Research, 153(3-4), 177-186. https://doi.org/10.1016/j.jvolgeores.2005.10.013

Spaans, K., Hreinsdóttir, S., Hooper, A., \& Ófeigsson, B. G. (2015). Crustal movements due to Iceland's shrinking ice caps mimic magma inflow signal at Katla volcano. Scientific Reports, 5(1). https://doi.org/10.1038/srep10285

Sturkell, E., Einarsson, P., Roberts, M. J., Geirsson, H., Gudmundsson, M. T., Sigmundsson, F., et al. (2008). Seismic and geodetic insights into magma accumulation at Katla subglacial volcano, Iceland: 1999 to 2005. Journal of Geophysical Research, 113, B03212. https://doi.org/ 10.1029/2006JB004851

Thordarson, T., Self, S., Miller, D. J., Larsen, G., \& Vilmundardóttir, E. G. (2003). Sulphur release from flood lava eruptions in the Veidivötn, Grímsvötn and Katla volcanic systems, Iceland. Geological Society of London, Special Publication, 213(1), 103-121. https://doi.org/10.1144/ GSL.SP.2003.213.01.07

Werner, C., Christenson, B. W., Hagerty, M., \& Britten, K. (2006). Variability of volcanic gas emissions during a crater lake heating cycle at Ruapehu volcano, New Zealand. Journal of Volcanology and Geothermal Research, 154(3-4), 291-302. https://doi.org/10.1016/j. jvolgeores.2006.03.017

Werner, C., Evans, W., Kelly, P., McGimsey, R., Pfeffer, M., Doukas, M., et al. (2012). Deep magmatic degassing versus scrubbing: Elevated CO2 emissions and C/S in the lead-up to the 2009 eruption of Redoubt volcano, Alaska. Geochemistry, Geophysics, Geosystems, 13, Q03015. https://doi.org/10.1029/2011GC003794

Werner, C., Hurst, T., Scott, B., Sherburn, S., Christenson, B. W., Britten, K., et al. (2008). Variability of passive gas emissions, seismicity, and deformation during crater lake growth at White Island volcano, New Zealand, 2002-2006. Journal of Geophysical Research, 113, B01204. https://doi.org/10.1029/2007JB005094

Werner, C., Kelly, P. J., Doukas, M., Lopez, T., Pfeffer, M., McGimsey, R., et al. (2013). Degassing of CO2, SO2, and H2S associated with the 2009 eruption of Redoubt volcano, Alaska. Journal of Volcanology and Geothermal Research, 259, 270-284. https://doi.org/10.1016/j. jvolgeores.2012.04.012 